\title{
Expression and Characterization of Membrane-Type 4 Matrix Metalloproteinase (MT4-MMP) and its Different Forms in Melanoma
}

\author{
Bettina Hieronimus $^{\mathrm{a}}$ Julian Pfohl ${ }^{\mathrm{a}}$ Christian Busch ${ }^{\mathrm{b}, \mathrm{c}}$ Lutz Graeve ${ }^{\mathrm{a}}$ \\ anstitute of Biological Chemistry and Nutrition, University of Hohenheim, Stuttgart, ${ }^{b}$ Section of \\ Dermatolo-Oncology, Department of Dermatology and Allergology, University of Tuebingen, \\ Tuebingen, Germany; 'Dermateam, Winterthur, Switzerland
}

\section{Key Words}

Glycosylphosphatidylinositol (GPI) - linked Proteins - N-glycosylation • Plasma membrane • Protein processing $\cdot$ RNA-protein relationship $\cdot$ Subcellular fractionation

\begin{abstract}
Background/Aims: Membrane-type matrix metalloproteinases (MT-MMPs) are expressed on the cell surface and hydrolyze extracellular matrix components and signaling molecules by which they influence cancer cell migration and metastasis. Two of the six known MT-MMPs are anchored to the plasma membrane via a GPI anchor, one of which is MT4-MMP. Only little is known about MT4-MMP expression, synthesis, regulation and degradation. Methods: We analyzed several human cancer cell lines as well as tissue homogenates using Western blotting and quantitative PCR for the expression of MT4-MMP. Organelles of SK-Mel-28 cells were separated using continuous Iodixanol gradients. Glycosylation of the SK-Mel-28 protein was studied via glucosidases and site directed mutagenesis of the MT4-MMP cDNA prior to transfection. Results: We found the MT4-MMP highly expressed in human melanoma cell lines as well as skin and melanoma tissue samples. Three forms of MT4-MMP with molecular masses of $45 \mathrm{kDa}, 58 \mathrm{kDa}$ and $69 \mathrm{kDa}$ were detected. Further, we demonstrate that the $58 \mathrm{kDa}$ form is the mature protein in the cell membrane, while the $69 \mathrm{kDa}$ form is its precursor found in intracellular compartments. The $69 \mathrm{kDa}$ forms are processed by furin cleavage in the Golgi apparatus. Moreover, we identified $\mathrm{Asn}^{318}$ as the single N-glycosylation site of MT4-MMP. Conclusion: We demonstrate the novel expression of MT4-MMP in melanocytic tissues and propose a precursor/product-relationship of the different forms of MT4-MMP in melanoma cells.

(C) 2017 The Author(s)

Published by S. Karger AG, Basel
\end{abstract}

\section{Introduction}

Matrix metalloproteinases (MMP) are a family of zinc-dependent endopeptidases that degrade matrix components and process signaling proteins. They play key roles in many 
physiological as well as pathophysiological processes like tissue remodeling in embryoor tumorigenesis, wound healing, apoptosis, angiogenesis, invasion or migration $[1,2]$. Although all MMPs share basic structures, the family members are diverse concerning their substrates, expression profiles, or interactions with other proteins and inhibitors. MMPs are either soluble or membrane bound, enabling them to operate at several locations. Membrane-type 4 matrix metalloproteinase (MT4-MMP or MMP17) and membrane-type 6 matrix metalloproteinase (MT6-MMP or MMP25) are the two glycosylphosphatidylinositol (GPI) anchored MMPs. The few known substrates of the GPI-anchored MT-MMPs differ from those of the other MT-MMPs, and tissue inhibitor of metalloproteinase 1 (TIMP-1) potently inhibits the GPI-anchored MT-MMPs [3, 4] whereas TIMP-1 fails to inhibit the others. Thus, they seem to have deviant functions from the other MT-MMPs. MT4-MMP was first cloned from a human breast cancer cDNA library in 1996 [5], but information on its biochemical functions is still scarce. Knockout mice for MT4-MMP mature normally [6], however those mice are prone to pressure-induced aneurism [7]. Many normal and tumor tissues (brain, breast cancer, leucocytes, ovary, spleen, uterus, prostate cancer) $[5,6,8-13]$ were shown to express MT4-MMP, though most of the studies focused on mRNA, and only few investigated protein expression. The list of identified MT4-MMPs substrates is short. In contrast to the other MT-MMPs it fails to cleave collagens [3] and barely activates proMMP2 [14]. However, its catalytic domain cleaves pro-TNF $\alpha$ and $\alpha 2$-macroglobulin [14], and the low density lipoprotein receptor-related protein [15]. While those substrates were identified with the isolated catalytic domain, only two substrates were tested in cellular systems - aggrecanase (ADAM-TS4) [16] and osteopontin [7]. Most studies so far used MT4-MMP-transfected cells with inconsistent results. MT4-MMP overexpression plays no role in proliferation [13], and was described to promote invasion [17-19], a finding which was contradicted by others [13]. MT4-MMP overexpression leads to increased vessel leakage and thereby facilitates intravasion of tumor cells into the bloodstream [20]. However, the underlying functions of MT4-MMP are barely understood, and to gain more insight, basic studies of MT4-MMP synthesis, modification, function and degradation are needed.

In this study, we focused on the different monomeric forms of MT4-MMP highly expressed in melanoma cell lines and tissue samples from skin and melanoma. We characterized the precursor, the active protein and a degradation product of MT4-MMP, and identified its N-glycosylation site at $\mathrm{Asn}^{318}$.

\section{Materials and Methods}

\section{Cell culture}

Non-melanoma cancer cell lines and their respective culture medium are given in Table 1. Human melanoma cell lines (1205LU, 451LU, A375, B16F1, BLM, IGR39, Mewo, SK-Mel-28, SK-Mel-30, WM115, WM3211, WM35, WM451, WM793) were cultured in Roswell Park Memorial Institute (RPMI) 1640 medium. All media were supplemented with $10 \%$ fetal bovine serum (FBS) and $1 \%$ penicillin and streptomycin and cells were maintained at $37^{\circ} \mathrm{C}$ in an atmosphere of $95 \%$ air and $5 \% \mathrm{CO}_{2}$. MDCK II clones were cultured in DMEM containing $10 \%$ fetal bovine serum (FBS) and $500 \mu \mathrm{g} / \mathrm{ml} \mathrm{G418.} \mathrm{Regular} \mathrm{tests} \mathrm{ruled} \mathrm{out} \mathrm{mycoplasma}$ contamination.

\section{Antibodies}

SDS-PAGE was performed and PVDF membranes were incubated with antibodies against MT4-MMP (1:500, r-mAB (ab51075), Abcam, United Kingdom), syntaxin-6 (1:1.000, r-mAB (ab140607), Abcam, United Kingdom), calnexin (1:20.000, r-mAB (AJ1119a), Abgent, San Diego, CA), $\mathrm{Na}^{+} \mathrm{K}^{+}-\mathrm{ATPase}(1: 1.000, \mathrm{r}-\mathrm{AB}$ polyclonal (\#3010), Cell Signaling Technologies, Danvers, MA) and $\beta$-actin (1:1.000, r-mAB (\#4970), Cell Signaling Technologies, Danvers, MA). Peroxidase-conjugated goat-anti-rabbit-IgG antibody was obtained from Millipore (1:5.000 or 1:10.000, AP132P, MerckMillipore, Billerica, MA).

\section{KARGER}


Table 1. Non-melanoma cancer cell lines. * All media were supplemented with $10 \%$ FCS and antibiotics. DMEM - Dulbecco's modified eagle's medium; LG - Low glucose; RPMI - Roswell Park Memorial Institute

\begin{tabular}{llcr} 
Name & Origin & Organism & Medium* \\
\hline 789-0 & Kidney Adenocarcinoma & human & RPMI \\
BeWo & Choriocarcinoma & human & DMEM \\
H35 & Hepatoma & rat & DMEM LG \\
HCS 2/8 & Chondrosarcoma & human & DMEM \\
Hec 1A & Uterus Adenocarcinoma & human & DMEM \\
Hela & Cervixcarcinoma & human & DMEM \\
HepG2 & Hepatocellular carcinoma & human & DMEM \\
HT-29 & Colon Adenocarcinoma & human & DMEM \\
Huh7 & Hepatocyte Carcinoma & human & DMEM \\
SW 620 & Colon Adenocarcinoma & human & DMEM \\
\hline
\end{tabular}

Tumor tissue collection and handling

Tissue samples were snap-frozen immediately upon removal and stored in liquid nitrogen until analysis. The homogenization of the tissue was done by mortar and pestle in a nitrogen bath, and the powder was used for protein homogenates. The protocol was approved by the Ethics Committee of the University of Tuebingen, Germany, and was conducted in adherence to the principles of the Declaration of Helsinki. Each patient signed a written consent form for the use of tissues for research purposes.

\section{Preparation of cell lysates and total RNA extracts}

Cells were scratched in Radio Immuno Precipitation Assay buffer (150 mM NaCl; 1.0\% NP-40; $0.5 \%$ Sodium-deoxycholate, $0.1 \%$ SDS (sodium dodecyl sulphate), $50 \mathrm{mM}$ Tris, $\mathrm{pH}$ 8.0) with addition of protease inhibitor cocktail $0.01 \%$ (Sigma Aldrich, St. Louis, MO) and incubated on ice for $20 \mathrm{~min}$. Cell debris was removed by centrifugation $\left(10 \mathrm{~min}, 16.000 \mathrm{rpm}, 4^{\circ} \mathrm{C}\right)$, and protein concentration was determined with Lowry protein determination kit (Bio Rad, United Kingdom). Samples were mixed with 2x sample buffer $( \pm 8 \mathrm{M}$ urea; $\pm 8 \mathrm{M} \beta$-mercaptoethanol; $50 \mathrm{mM}$ Tris/HCl pH 6,8; 1,6\% SDS; 7\% glycerol; 0,0016\% bromphenol blue $)$ and optionally heated $\left(10 \mathrm{~min}, 80^{\circ} \mathrm{C}\right)$ followed by SDS-Page and immunoblot analyses with various antibodies. RNA was isolated from $2 \times 10^{6}$ cells with RNeasy kit (Qiagen, Netherlands) following the manufacture's protocol. RNA amount and integrity were analyzed by measuring the optical density.

cDNA synthesis and real time quantitative PCR

For cDNA synthesis $1 \mu \mathrm{g}$ total RNA was applied to the iScript cDNA Synthesis Kit (BioRad, United Kingdom) as described in the manufacture's protocol. cDNA (corresponding to $1 \mathrm{pg}$ to $100 \mathrm{ng}$ total RNA) was added to 2X SYBR Green reaction mix containing $4 \mathrm{pM}$ primer pair per reaction. Samples were run in duplicates from three independent experiments in addition to standards $\left(10^{2}-10^{7}\right.$ copies $)$ and no template controls for each gene. Real time quantitative PCR was performed by CFX96 system (BioRad, United Kingdom) using the same thermal cycle conditions for all primers $\left(5 \mathrm{~min}, 95^{\circ} \mathrm{C}\right.$ for hot start followed by 40 cycles of $10 \mathrm{~s}, 95^{\circ} \mathrm{C} ; 15 \mathrm{~s}, 60^{\circ} \mathrm{C}$ and $29 \mathrm{~s}, 72^{\circ} \mathrm{C}$ ). $\mathrm{C}_{\mathrm{T}}$ analysis was done with BioRad CFX Manager 3.1 software, and values were normalized with the geometric mean of the three reference genes (GAPDH, $\beta$-actin and $\alpha-2$ microglobulin). Table 2 lists the primers used for quantitative PCR.

Site directed mutagenesis

Site directed mutagenesis was performed using the QuikChange Site-Directed Mutagenesis Kit from Agilent Technologies and followed the manufacture's protocol. Primers used for the SDM are given in Table 2. Mutations were verified by DNA sequencing, done by Source Bioscience, Berlin.

Subcellular fractionation

For subcellular fractionation, cells from four confluent $10 \mathrm{~cm}$ plates were scratched in homogenization buffer $(0,25 \mathrm{M}$ sucrose, $1 \mathrm{mM}$ EDTA, $10 \mathrm{mM}$ Hepes- $\mathrm{NaOH}, \mathrm{pH} 7,4)$ and subsequently homogenized using 


\section{Cellular Physiology Cell Physiol Biochem 2017;42:198-210 \begin{tabular}{l|l} 
and Biochemistry Published online: May 18, 2017 & $\begin{array}{l}\text { D } 2017 \text { The Author(s). Published by S. Karger AG, Basel } \\
\text { www.karger.com/cpb }\end{array}$ \\
\hline
\end{tabular}}

Hieronimus et al.: MT4-MMP Forms in Melanoma Cell Lines

Table 2. Sequence of the Oligonucleotides for qPCR and mutagenesis. PCR - polymerase chain reaction; MT4-MMP - membrane type 4 matrix metalloproteinase; GAPDH - glyceraldehyde 3-phosphate dehydrogenase; F- forward; R - reverse

\begin{tabular}{|c|c|c|}
\hline Method & Gene & Sequence $\left(5^{\prime} \rightarrow>3^{\prime}\right)$ \\
\hline \multirow[t]{8}{*}{ Quantitative PCR } & MT4-MMP & F $\quad$ CTG GGA GTG GAG TGG CTA AGC A \\
\hline & & TTT CAT CAG GGC CAG GGT GG \\
\hline & GAPDH & ATG ACA TCA AGA AGG TGG TGA \\
\hline & & CTG TAG CCA AAT TCG TTG TCA \\
\hline & $\beta$-Actin & GGA TGC AGA AGG AGA TCA CTG \\
\hline & & CGA TCC ACA CGG AGT ACT TG \\
\hline & $\beta 2$ Microglobulin & CGT GTG AAC CAT GTG ACT TT \\
\hline & & AAA GCA AGC AAG CAG AAT TT \\
\hline \multirow[t]{4}{*}{ Site directed mutagenesis } & N137Q & GGA CCC TCC ACG ACA GTT GCC TCT TGT TCC ACT TG \\
\hline & & CAA GTG GAA CAA GAG GCA ACT GTC GTG GAG GGT CC \\
\hline & N318Q & GGG CGC TGG ACC GTT GGT CTG GGG GCT CC \\
\hline & & GGA GCC CCC AGA CCA ACG GTC CAG CGC CC \\
\hline
\end{tabular}

gentleMACS Dissociator (Miltenyi Biotec GmbH, Germany). Membranes from the post-nuclear supernatant were pelleted by ultracentrifugation at $100.000 \mathrm{xg}$ for $1 \mathrm{~h}$ at $4^{\circ} \mathrm{C}$ (Rotor: SW41Ti, Beckman Coulter, Pasadena, CA). A continuous 1-25\% (w/v) iodixanol gradient was generated from the bottom using a two-chamber gradient maker and underlaid with the homogenized membrane pellet. After ultracentrifugation for $3 \mathrm{~h}$, 200.000xg at $4^{\circ} \mathrm{C}$ (Rotor: SW41Ti, Beckman Coulter, Pasadena, CA) $500 \mu \mathrm{l}$ fractions were taken from top with a piston gradient fractionator (BioComp Instruments, Fredericton, Canada) and fractions 2-22 were applied to two SDS-PAGE gels. Gels were blotted onto PVDF membranes and analyzed with the indicated antibodies. Ioxidanol concentration was determined via refractometry.

\section{Surface biotinylation, proteinase K and PI-PLC treatment}

Proteinase K. SK-Mel-28 cells were washed twice and incubated on ice with proteinase $\mathrm{K}(100 \mu \mathrm{g} / \mathrm{ml}$ in PBS, 1 mM EDTA) for 30 min while gently shaking. Cells were washed and lysed in RIPA buffer.

Surface biotinylation. The method was adapted from Buk et al. [21]. All steps were performed on ice. Confluent SK-Mel-28 cell were washed with $\mathrm{PBS}^{++}$three times for $5 \mathrm{~min}$ and once for $15 \mathrm{~min}$ with a biotinylation buffer (120 mM NaCl, $20 \mathrm{mM} \mathrm{NaHCO3,} 1 \mathrm{mM} \mathrm{MgCl}_{2}, 0.1 \mathrm{mM} \mathrm{CaCl}$, pH 8.5). Incubation with sulfo-NHS-biotin $(0,5 \mathrm{mg} / \mathrm{ml})$ was performed twice for 20 minutes. Remaining biotin was removed by one wash for 15 min with biotinylation medium (RPMI, 0.2\% BSA, 20 mM HEPES, pH 7.4) and three washes with PBS- for $5 \mathrm{~min}$. Cells were lysed in $1 \mathrm{ml}$ RIPA and lysates were precipitated overnight with NeutrAvidin beads in an overhead shaker at $4^{\circ} \mathrm{C}$. Beads were washed 4 times with RIPA and boiled 5 min in 2x Laemmli buffer to remove the protein. The supernatant from the overnight incubation was precipitated with TCA/acetone. Equal amounts of protein were loaded onto an SDS-PAGE.

PI-PLC. Serum starved SK-Mel-28 cells were incubated with $0.2 \mathrm{U} / \mathrm{ml}$ of phosphoinositide phospholipase $\mathrm{C}$ (PI-PLC) for $3 \mathrm{~h}$ at $37^{\circ} \mathrm{C}, 5 \% \mathrm{CO}_{2}$. Medium was precipitated with $12 \%$ TCA (w/v) for 30 min on ice and pellets subsequently washed twice with acetone $\left(-20^{\circ} \mathrm{C}\right)$. Cells were lysed as above. All experiments included negative controls, incubated with the respective medium only.

Stimulation of cells

Subconfluent SK-Mel-28 cells were treated with medium supplemented with the respective substance of interest (furin inhibitor (N2-(1-oxodecyl)-L-arginyl-L-valyl-N-[(1S)-4-[(aminoiminomethyl)amino]-1(2-chloroacetyl)butyl]-L-lysinamide) - Cayman Chemicals, Ann Arbor, USA, tunicamycin and brefeldin A Sigma Aldrich, St. Louis, USA). Cells were lysed at the indicated time points and $30 \mu \mathrm{g}$ protein were applied to SDS-PAGE.

\section{Deglycosylation with EndoH and PNGase F}

$20 \mu \mathrm{g}$ of SK-Mel-28 lysates were digested with EndoH kit (NEB, Ipswich, USA) or PNGase F kit (NEB) according to the manufacturer's instructions. The samples were subsequently applied to SDS-PAGE. 


\section{Results}

Melanocytic tissues and skin express MT4-MMP protein

Though many cell lines and tissues express MT4-MMP mRNA $[5,8,10]$, the protein is less abundant. Therefore, most studies on MT4-MMP were performed with transfected cell lines $[13,14,17,22-24]$. To find a suitable model to study the MT4-MMP and its natural regulations we analyzed different cancer cell lines for both MT4-MMP mRNA and protein expression. Of the tested non-melanoma cancer cell lines, only MCF-7 breast cancer cells showed slight MT4-MMP protein bands in the western blot (Fig. 1A). However, we found MT4MMP protein to be abundantly expressed in 11 out of 14 tested melanoma cell lines (Fig. 1B). To our knowledge, this is the first report of MT4-MMP protein expression in melanoma cells. Under reducing conditions, the protein is detected in SDS-Page at three molecular masses: $69 \mathrm{kDa}, 58 \mathrm{kDa}$ and $45 \mathrm{kDa}$. All three forms present as double bands and in amounts varying between the different cell lines. Figures 1C and 1D depict the MT4-MMP mRNA expression level in non-melanoma and melanoma cell lines. The mRNA results are consistent with the western blot data in all cell lines except Mewo and SK-Mel-30, which express MT4-MMP mRNA but hardly any protein. To exclude that the MT4-MMP expression in melanoma cell lines is a cell culture artifact, skin and melanoma tissues were tested for their MT4-MMP protein. To this end, we analyzed human biopsies of normal skin $(n=4)$, nevus cell nevi $(n=$ $9)$, primary melanoma $(n=12)$, and melanoma metastases $(n=18)$. All of the tested 43 tissue samples were positive for the MT4-MMP protein. Figure 2 shows a representative subset. Although we detected MT4-MMP protein in all samples, the relative amount of the different molecular weight forms varied considerably. Under reducing conditions (Fig. 2A), the $45 \mathrm{kDa}$ and $58 \mathrm{kDa}$ forms were mostly present, again as double bands, but only few tissue samples contained the $69 \mathrm{kDa}$ forms. Under non-reducing conditions one band at $110 \mathrm{kDa}$ was mainly present (Fig. 2B). Sohail et al. previously characterized this form as a homo-dimer in mouse tissues and transfected MDCK cells [19]. Interestingly, we also detected the $69 \mathrm{kDa}$ forms under non-reducing conditions suggesting a monomeric state (Fig. 2B). The SK-Mel-28 cell line was used in the following experiments as it showed the highest detectable levels of the MT4-MMP protein.

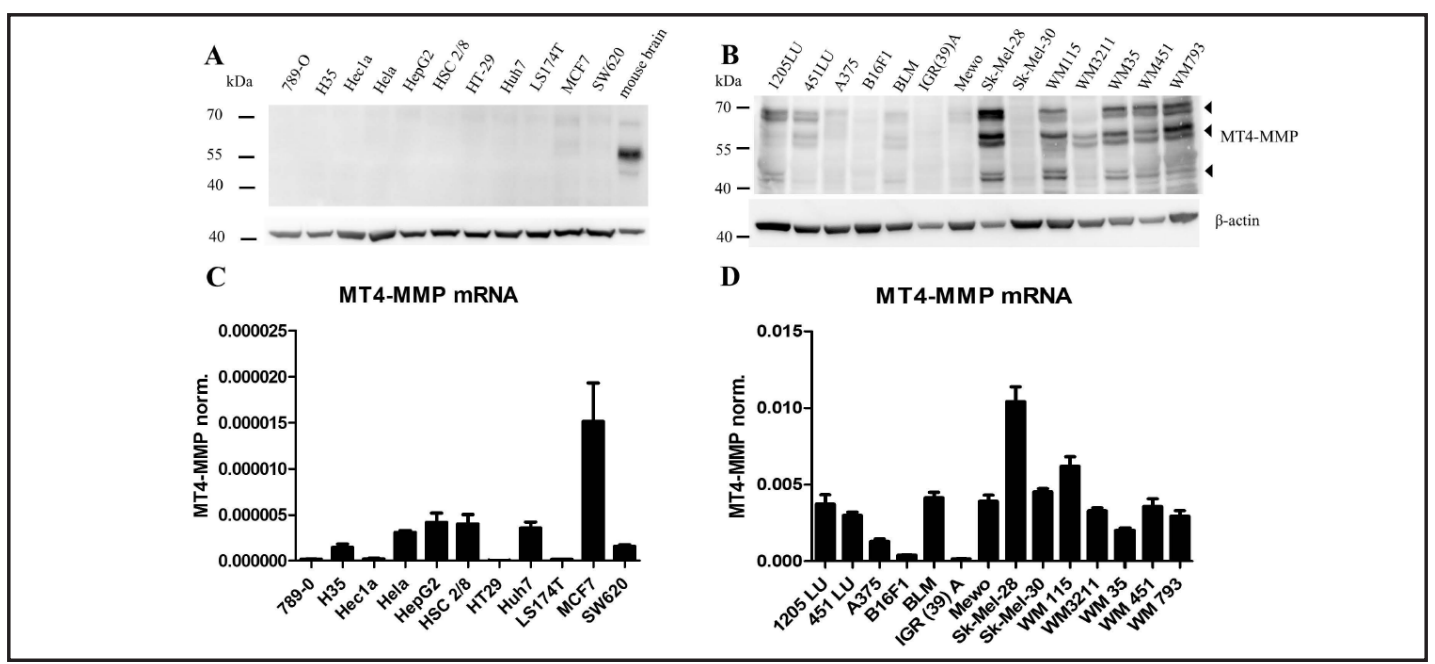

Fig. 1. MT4-MMP protein and mRNA in cancer cell lines. MT4-MMP protein expression was analyzed by SDS-PAGE and Western blotting in (A) 11 non-melanoma cancer cell lines and (B) 14 melanoma cell lines using mouse brain lysate as positive control. $30 \mu \mathrm{g}$ of protein per sample was applied to the gel. MT4-MMP mRNA expression in non-melanoma (C) and several melanoma cell lines (D) was determined as ratio from copy numbers of MT4-MMP against the geometric mean of the copy numbers of $\beta$-actin, $\beta$-2-microglobulin and GAPDH. Means are presented in \pm SEM. Each experiment was repeated three times, and samples were measured in duplicates. Please note the different scales in C and D. 


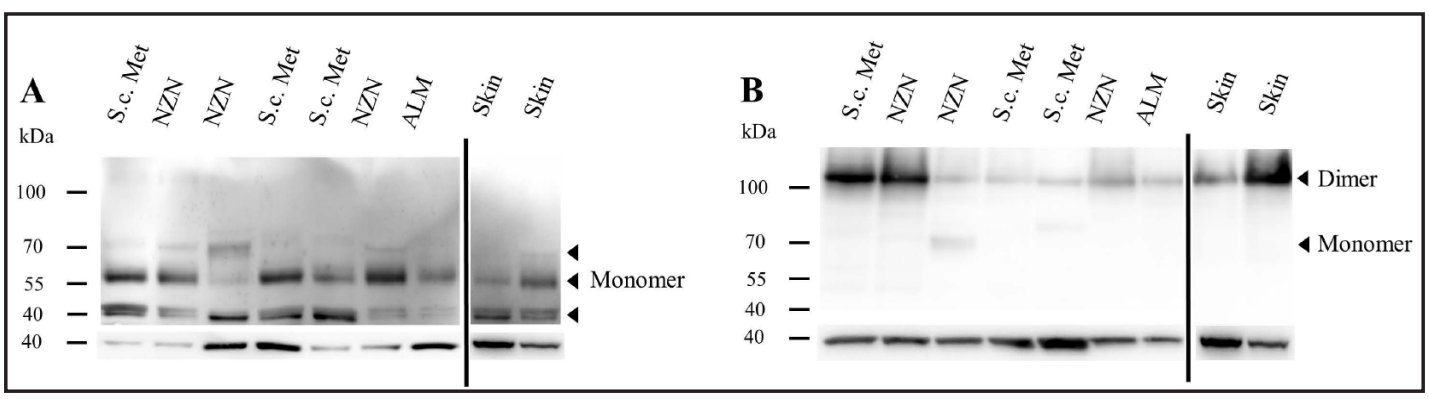

Fig. 2. MT4 MMP protein expression in melanoma and skin tissue samples. $30 \mu \mathrm{g}$ of protein were subjected to SDS-PAGE and Western blotting. Representative images of 43 samples in total. Skin samples were run on separate blots. A Protein samples treated with $2 \mathrm{x}$ sample buffer with urea and $\beta \mathrm{ME}$ and boiled (reducing conditions. B Samples were suspended in 2x sample buffer without urea or $\beta M E$ (non-reducing conditions). Lower panel $\beta$-actin. NZN - nevus cell nevus; ALM - acral lentiginous melanoma; S.c. met. - subcutaneous metastasis

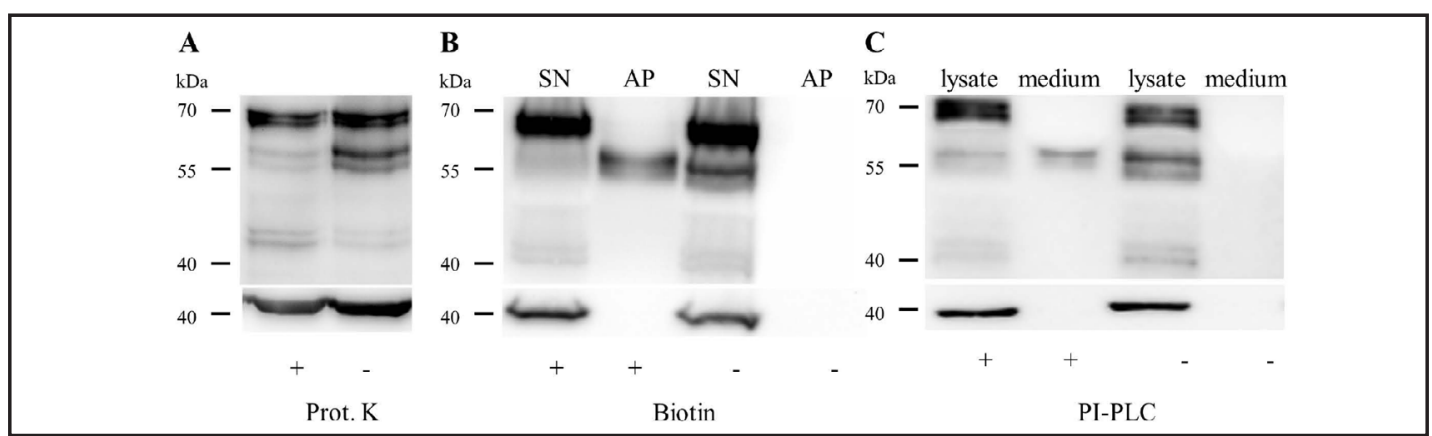

Fig. 3. Surface localization of MT4-MMP. A Cells were incubated on ice with or without proteinase K (100 $\mathrm{mg} / \mathrm{ml}$ in $\mathrm{PBS}^{-}$) for $30 \mathrm{~min}$. B Surface proteins were labeled with sulfo-NHS-biotin and after lysis precipitated with neutravidin beads (AP). Negative control was treated equally without adding sulfo-NHS-biotin. Supernatant was TCA precipitated after removal of the avidin beads (SN). C Serum starved cells were digested with phosphoinositide phospholipase $\mathrm{C}(0,2 \mathrm{U} / \mathrm{ml})$ for $3 \mathrm{~h}$. Cells were lysed as described in the Method section and medium was precipitated with TCA. All experiments were repeated three times. MT4-MMP (upper panel), and $\beta$-actin detection (lower panel).

The $58 \mathrm{kDa}$ form of MT4-MMP is exposed to the outside of the cell

The MT4-MMP is a GPI-anchored protein and therefore faces the cell exterior. We performed three different experiments to analyze which of the different MT4-MMP forms were located at the plasma membrane (Fig. 3). In the first experiment, we used proteinase $\mathrm{K}$, a broad-spectrum peptidase, to digest possible cell surface-bound forms of MT4-MMP. To this end, SK-Mel-28 cells were incubated with proteinase $\mathrm{K}$ at $4^{\circ} \mathrm{C}$ for $30 \mathrm{~min}$. Western blot analysis demonstrated that the $58 \mathrm{kDa}$ MT4-MMP variants were no longer detectable in the proteinase K-treated SK-Mel-28 cell lysates while the $69 \mathrm{kDa}$ and $45 \mathrm{kDa}$ variants were unaffected by proteinase K treatment (Fig. 3A). In a second experimental approach, we performed surface biotin labeling using sulfo-NHS-biotin, which forms covalent bonds with amino acid residues of surface exposed proteins. Surface labeling with biotin and subsequent avidin precipitation of the labeled proteins resulted in an exclusive precipitation of the $58 \mathrm{kDa}$ MT4-MMP forms whereas the $69 \mathrm{kDa}$ and $45 \mathrm{kDa}$ forms remained in the supernatant (Fig. 3B). As a third experiment, we used the enzyme phosphoinositide phospholipase C (PIPLC) to cleave the phosphodiester bond of the phosphatidylinositol anchor which results in the release of a GPI-linked proteins into the medium [25]. In line with the results gained before, the medium from PI-PLC treated SK-Mel-28 cells contained only the $58 \mathrm{kDa}$ forms (Fig. 3C), whereas the other two forms were found in the cell lysate (Fig. 3C). From all three experiments, we conclude that the $58 \mathrm{kDa}$ MT4-MMP forms were the only forms exposed to the cell exterior and that the $69 \mathrm{kDa}$ and the $45 \mathrm{kDa}$ variants were localized intracellularly. 


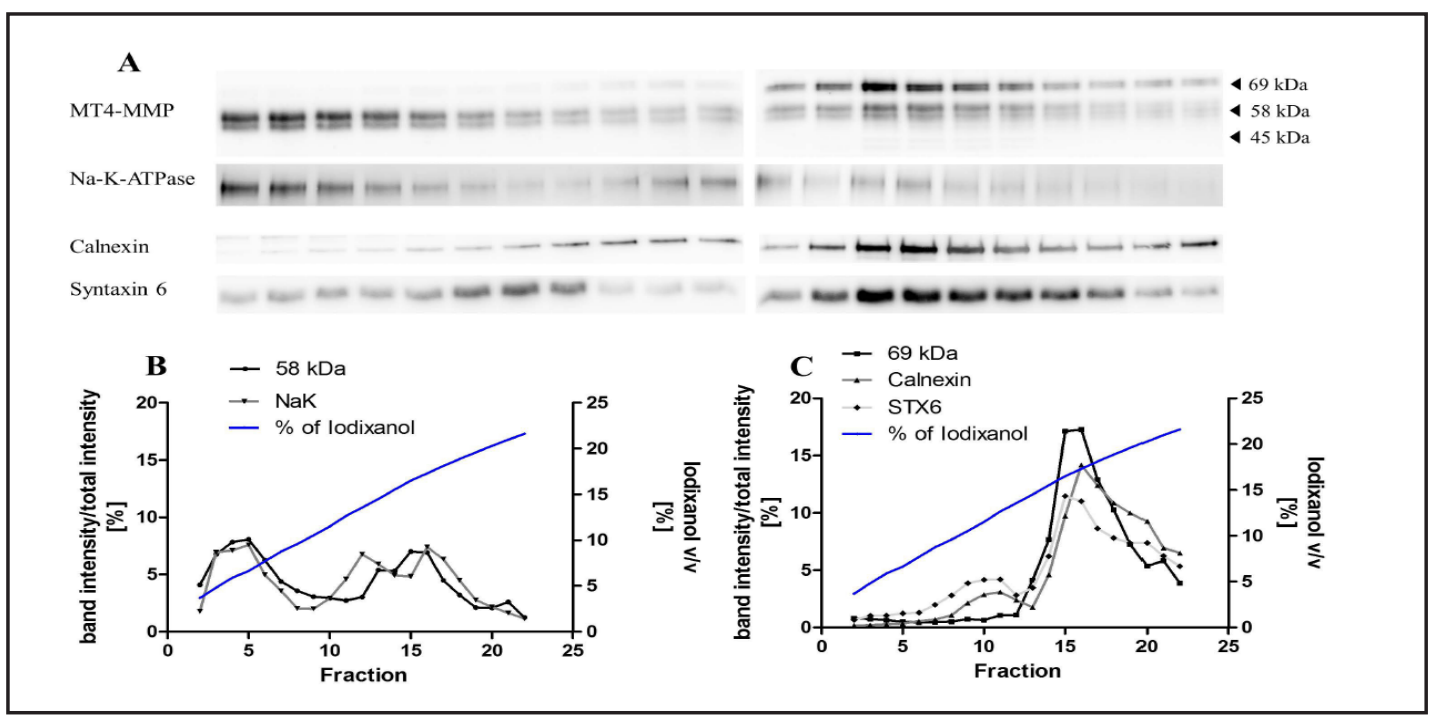

Fig. 4. Distribution of MT4-MMP forms in subcellular membranes. A The membrane fraction of SK-Mel-28 cells was applied to a 1-25\% linear iodixanol gradient. Equal volumes of 21 collected fractions were loaded to two SDS-PAGE gels. B\&C Desitometric analysis of the band intensities. $58 \mathrm{kDa}$ form was plotted with Na-K-ATPase and $69 \mathrm{kDa}$ form with STX6 and Calnexin. Data represents the means of three independent experiments. Na-K-ATPase - plasma membrane; Syntaxin 6 - Golgi apparatus; calnexin - endoplasmatic reticulum.

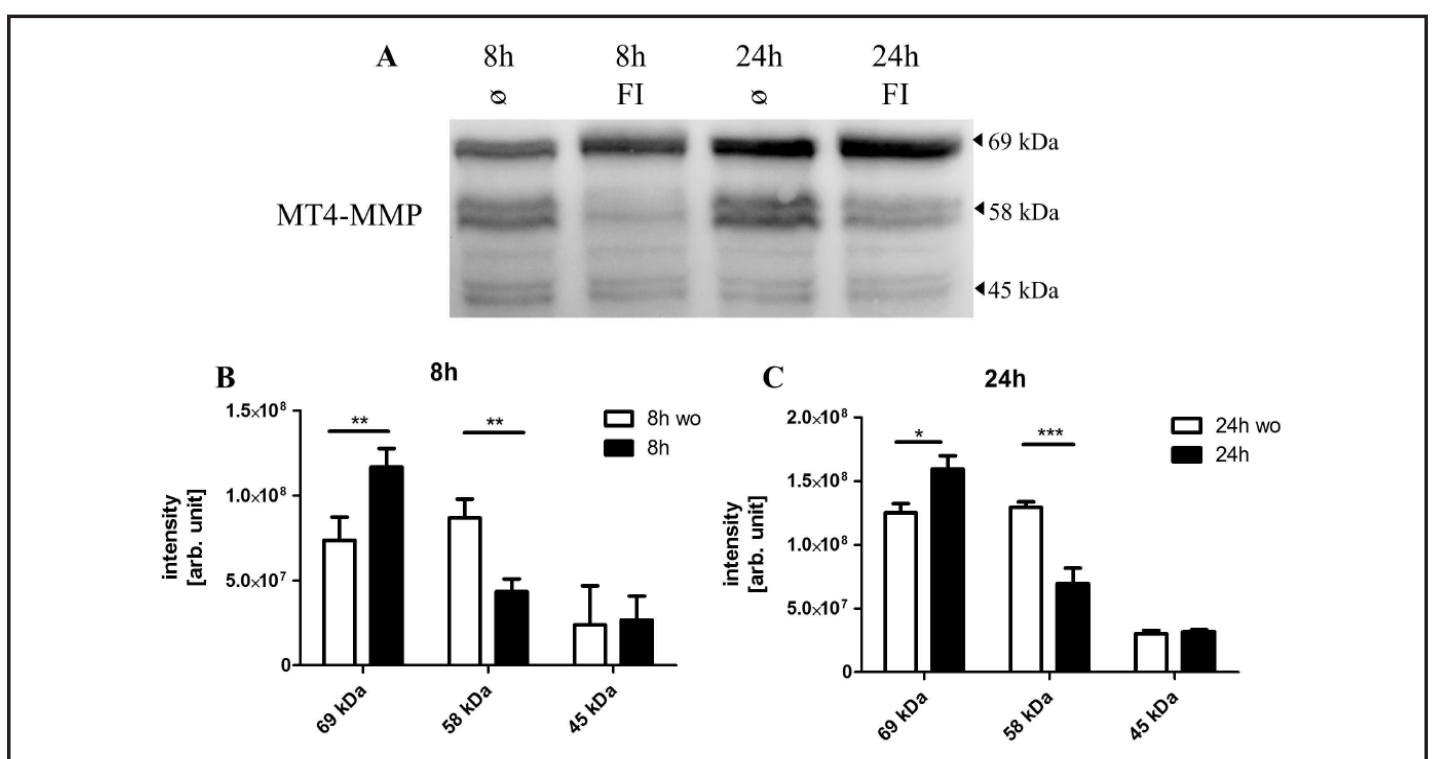

Fig. 5. MT4-MMP upon furin inhibition. Subconfluent SK-Mel-28 cells were incubated with a furin inhibitor (N2-(1-oxodecyl)-L-arginyl-L-valyl-N-[(1S)-4-[(aminoiminomethyl)amino]-1-(2-chloroacetyl)butyl]-L-lysinamide) for $8 \mathrm{~h}$ and $24 \mathrm{~h}$. A Cell lysates were subjected to SDS-page with subsequent western blot and immunodetection of MT4-MMP. B\&C Desitometric analysis of the band intensities. Double bands were analyzed as one band. $\otimes$ - untreated sample. Experiment was repeated three times $(n=3)$, and samples were measured in technical duplicates. Data shown as mean \pm SD. 2-way ANOVA, Bonferroni posttest, $* \mathrm{P} \leq 0.5$, ${ }^{* *} \mathrm{P} \leq 0.01$, $* * * \mathrm{P} \leq 0.001$.

We therefore next analyzed the subcellular location of the intracellular forms of the MT4MMP. 


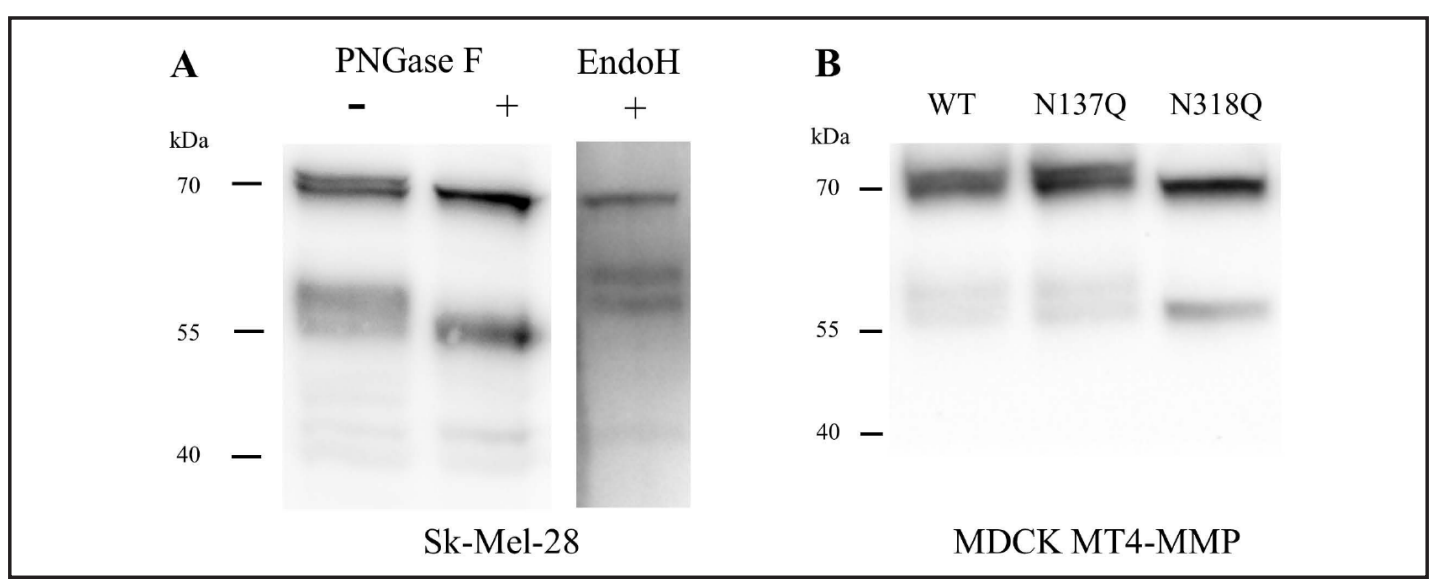

Fig. 6. MT4-MMP is an N-glycosylated protein. MT4-MMP detection. A SK-Mel-28 cell lysates were digested with PNGase F (P0704S, NEB) or EndoH (P0702S, NEB). Negative control was treated equally. B MDCK cells transfected with wt-MT4-MMP, MT4-MMP-N140Q and MT4-MMP-N321Q. 30 $\mathrm{g}$ of protein were loaded per lane. Representative pictures of three independent experiments.

The $69 \mathrm{kDa}$ variants of MT4-MMP are found in the ER/Golgi compartment

To this end, membrane fractions were prepared from SK-Mel-28 cell homogenates and applied to a continuous iodixanol gradient (0-25\%). 22 fractions were subjected to western blotting and tested for MT4-MMP as well as the organelle markers calnexin (ER), syntaxin 6 (Golgi apparatus) and $\mathrm{Na}^{+} \mathrm{K}^{+}$-ATPase (plasma membrane). In the iodixanol gradient, the $58 \mathrm{kDa}$ forms separated from the $69 \mathrm{kDa}$ forms (Fig. 4A). When the signal intensities of the proteins were plotted in a diagram (Fig. 4B), the $69 \mathrm{kDa}$ MT4-MMP forms preferentially aligned with markers for the ER (calnexin) and Golgi apparatus (syntaxin 6). In contrast, the $58 \mathrm{kDa}$ forms migrated with the plasma membrane marker $\left(\mathrm{Na}^{+} \mathrm{K}^{+}\right.$-ATPase). This suggested that the $69 \mathrm{kDa}$ variants might be the intracellular precursor of the $58 \mathrm{kDa}$ forms. For the $45 \mathrm{kDa}$ forms, only a marginal signal was detectable in the immunodetection.

Furin processes the MT4-MMP

All MMPs are synthesized as precursors, carrying a propeptide that blocks the enzymatic domain. In the literature, it was often stated but never shown that the MT4-MMP is activated by furin based on its furin cleavage consensus sequence. We used a chemical furin inhibitor to assess whether the activation of the MT4-MMP is achieved by furin. Figure 5 shows the resulting bands from the furin inhibition. The $58 \mathrm{kDa}$ band decreased upon furin inhibition while the $69 \mathrm{kDa}$ increased significantly (Fig. 5). The amount of the $45 \mathrm{kDa}$ forms remained unaltered.

The MT4-MMP is N-glycosylated at $\mathrm{Asn}^{318}$

The observation that all three MT4-MMP forms appeared as double bands suggested that they might represent differentially glycosylated forms. Sohail et al. reported that the MT4-MMP is N-glycosylated in transfected MDCK cells [19]. In order to confirm this in cells that naturally express MT4-MMP, we treated SK-Mel-28 cell lysates with EndoH, which only cleaves immature mannose rich $\mathrm{N}$-glycosylations, and with PNGase F, which cleaves all $\mathrm{N}$-glycosylations. The slower migrating of all three double bands disappeared after PNGase $\mathrm{F}$ treatment (Fig. 6A), while the $58 \mathrm{kDa}$ form still presented as double band after EndoH incubation. We concluded that the MT4-MMP is partially N-glycosylated and the $45 \mathrm{kDa}$ and $69 \mathrm{kDa}$ forms carry immature N-glycosylations. NetNGlyc 1.0 predicted two possible glycosylation sites, $A_{s n^{137}}$ and $A s n^{318}$. To explore which of the two potential sites is used, we individually replaced the two Asn by Gln in an MT4-MMP expression vector and stably transfected MDCK cells with the resulting plasmids. Western blotting and immunodetection of the clones identified $\mathrm{Asn}^{318}$ as the only used N-glycosylation site (Fig. 6B). The MT4-MMP 


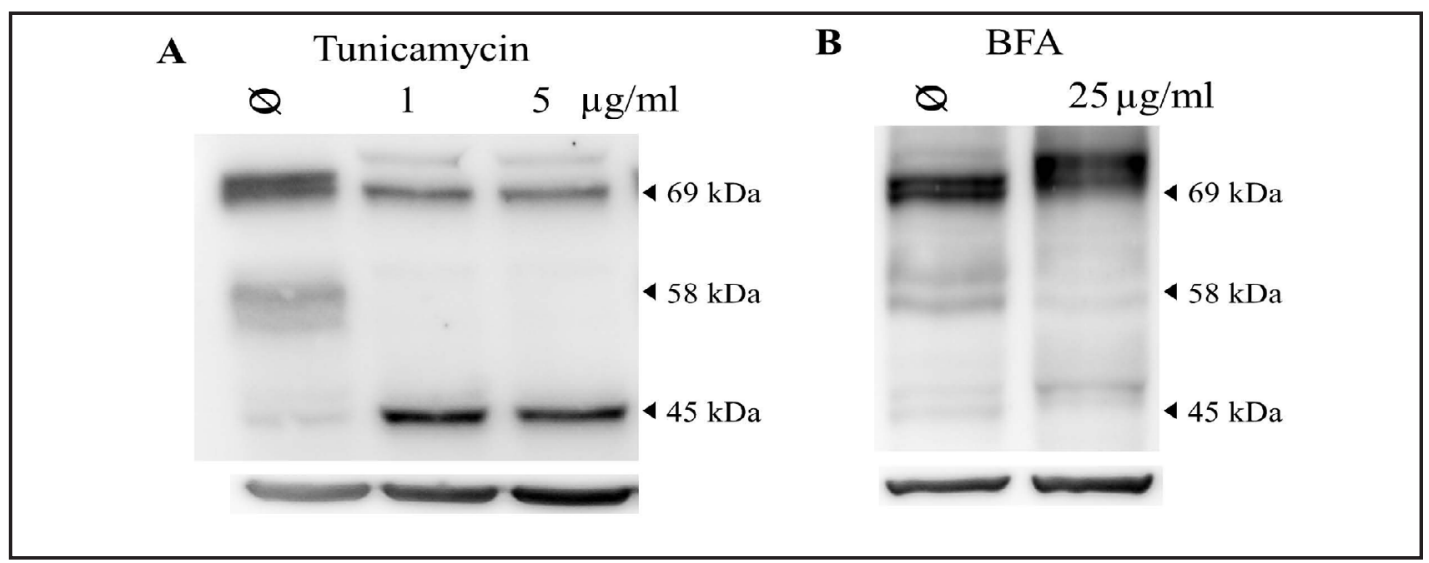

Fig. 7. ER stress influences the expression pattern of the MT4-MMP variants. Subconfluent SK-Mel-28 cells were incubated with A two concentrations of tunicamycin $(1 \mu \mathrm{g} / \mathrm{ml}$ and $5 \mu \mathrm{g} / \mathrm{ml})$ or with B Brefeldin A (BFA) and lysed subsequently. Negative control $(\otimes)$ was incubated with the respective amount of DMSO. Lysates were subjected to SDS-PAGE and western blot. The experiments were repeated three times. MT4-MMP (upper panel), and $\beta$-actin detection (lower panel).

N318Q mutant did not show a difference in protein half-life when compared to the wild-type form in MDCK cells (data not shown). In addition, neither protein sorting to lipid rafts or to the apical plasma membrane nor dimerization was affected by the lack of N-glycosylation (data not shown).

The $45 \mathrm{kDa}$ form is a degradation product of the $69 \mathrm{kDa}$ form

Tunicamycin was used to further study the glycosylation. Upon tunicamycin treatment, the $58 \mathrm{kDa}$ form disappeared from the western blot while the bands of the $45 \mathrm{kDa}$ and $69 \mathrm{kDa}$ variants increased in their intensity with only the lower of the double bands being present (Fig. 7A). As tunicamycin induces ER stress, brefeldin A (BFA) was used to test whether the vast increase of the $45 \mathrm{kDa}$ form might be due to an ER stress response. Upon treatment with $\mathrm{BFA}$, the $58 \mathrm{kDa}$ bands fainted, while the intensity of the $69 \mathrm{kDa}$ increased and the $45 \mathrm{kDa}$ form was unaltered compared to the untreated control (Fig. 7B). After both treatments tunicamycin and BFA - a new band appeared at $\sim 75 \mathrm{kDa}$.

\section{Discussion}

Compared to other MMPs little is known about the function, regulation, synthesis or degradation of MT4-MMPs. One obstacle of the past was that all cell lines analyzed to date expressed very little MT4-MMP protein. In this study we succeeded to identify a cell type that abundantly expresses the MT4-MMP protein allowing us to study its synthesis and processing in an authentic cell type. To our knowledge, this is the first report of MT4-MMP expression in melanoma cells. Of note, SW 620, HeLa and MCF7 cells $[8,11]$ were reported to express MT4-MMP mRNA before, but these studies were lacking protein expression data. The MT4-MMP mRNA expression in MCF7 cells was at least one order of magnitude lower than in melanoma cells. Two of our tested melanoma cell lines expressed the MT4-MMP mRNA abundantly but also failed to translate it into protein. This may be due to alternative splicing, point mutations, miRNA or deletions in this gene. The correlation between mRNA and protein abundance or the lack of it has been described before, and a review on the topic is available [26].

Tissue samples of skin, non-transformed nevi, primary melanoma, and melanoma metastases were also tested positive for MT4-MMP - excluding that the MT4-MMP expression in melanoma cell lines was a cell culture artifact. The MT4-MMP was primarily present as

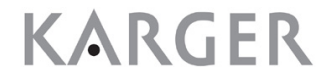




\section{Cellular Physiology Cell Physiol Biochem 2017;42:198-210 \begin{tabular}{ll|l} 
and Biochemistry & $\begin{array}{l}\text { DOI: 10.1159/000477311 } \\
\text { Published online: May 18, } 2017\end{array}$ & $\begin{array}{l}\text { O 2017 The Author(s). Published by S. Karger AG, Basel } \\
\text { www.karger.com/cpb }\end{array}$ \\
\cline { 2 - 3 }
\end{tabular} \\ Hieronimus et al.: MT4-MMP Forms in Melanoma Cell Lines}

dimers as the native protein blots indicate (Fig. 2A). The dimerization might be crucial for MT4-MMPs functions. Only one of the tested samples contained the $69 \mathrm{kDa}$ form. The $69 \mathrm{kDa}$ form was detected in both - the native and the denatured sample. This protein form is mostly referred to as MT4-MMP in the present literature. In contrast, the $58 \mathrm{kDa}$ and $45 \mathrm{kDa}$ forms were abundantly expressed in all tested homogenates independent of their origin.

Köhrmann et al. compared mRNA of multiple MMPs from cancer and normal breast tissues [27]. The MT4-MMP mRNA levels in cancerous and normal tissue were comparable; thus, they concluded that the protein expression should be unaffected. However, the findings were not corroborated by protein expression data. In contrast to the latter results, Chabotteaux et al. described elevated MT4-MMP mRNA and protein in cancerous compared to normal breast tissue [13]. Preliminary studies in our lab with primary human cells indicated that melanocytes expressed MT4-MMP, whereas skin fibroblasts or keratinocytes showed no MT4-MMP expression (data not shown). The master regulator of melanocyte development is the microphthalmia-associated transcription factor (MITF). Its expression is limited to melanocytes, osteoclasts and mast cells. A study on the targets of the MITF revealed its influence on MT4-MMP expression [28]: MT4-MMP expression increased by 27 fold upon MITF induction. Taken together, we conclude that skin/melanoma is a suitable model to study MT4-MMP, as the protein expression here seems to be higher than in those cell lines or tissues studied before.

In SDS-PAGE, the immunoreactive MT4-MMP proteins migrated as double bands with three different molecular masses, $45 \mathrm{kDa}, 58 \mathrm{kDa}$ and $69 \mathrm{kDa}$. We found those forms in most tested melanoma cell lines as well as in the tissue samples. Our experiments with proteinase $\mathrm{K}$, biotin surface labeling and PI-PLC show that the $58 \mathrm{kDa}$ forms are GPI-linked and located at the plasma membrane facing the outside of the cell. The other two forms are thus intracellular variants since they were unaffected by the different treatments. In the continuous iodixanol gradient, the $69 \mathrm{kDa}$ forms floated with ER/Golgi markers suggesting that they were located in these organelles. The co-localization of the $58 \mathrm{kDa}$ form and the $\mathrm{Na}^{+} \mathrm{K}^{+}$-ATPase corroborates the plasma membrane localization of this form. After fractionation, only marginal amounts of the $45 \mathrm{kDa}$ form could be recovered from the gradient. Also the 100.000xg membrane pellets (see methods) that were applied to the gradient centrifugation lack the $45 \mathrm{kDa}$ forms (data not shown). This form is therefore neither membrane-associated nor does it reside inside those organelles contained in the pellet.

Sohail et al. found the MT4-MMP to be N-glycosylated, a finding, which we confirmed in SK-Mel-28 cell lysates using glycosylases. Further, we identified the glycosylation site by substituting the respective putative $\mathrm{Asn}^{137}$ and $\mathrm{Asn}^{318}$ with glutamine. Our results in transfected MDCK cells identified Asn ${ }^{318}$ as the only N-glycosylation site. The double bands in the western blot indicated incomplete glycosylation of this site. The partial glycosylation process may influence the effects or stability of MT4-MMP due to steric differences in the protein structure.

Just recently, a comprehensive review on MMP glycosylation was published by Boon et al. [29] where they summarized the current knowledge on MMP glycosylation. As already shown for other MMPs, MT4-MMP glycosylation is only partial. A possible influence of the glycosylation on the functions of MT4-MMP is hard to study at this point due to the unknown substrates and degradation pathway. In our hands, the glycosylation had no influence on the protein half live or sorting to the apical membrane in transfected MDCK cells (data not shown).

EndoH digest revealed that the $45 \mathrm{kDa}$ form carries high mannose - and therefore immature - N-glycosylations (Fig. 6A). The generation of the $45 \mathrm{kDa}$ forms is independent of furin cleavage (Fig. 5) and the amount of the form increases upon ER stress (Fig. 7). We conclude from the results gained here that it is a degradation product of the $69 \mathrm{kDa}$ form, which is degraded prior to its full maturation. We assumed that the variant might be generated by ER-assisted protein degradation (ERAD), but proteasome inhibition did not alter the amount of $45 \mathrm{kDa}$ MT4-MMP (data not shown). 
Interestingly, transfected MDCK cells did not express the $45 \mathrm{kDa}$ forms at all. Similar small molecular weight variants were described for MT6-MMP in human neutrophils as well as in MT6-MMP transfected Cos-7 cells [30, 31]. Those small MT6-MMP forms partly originated from autocatalysis. Autocatalytic degradation was described for the MT4-MMP [22], however, the here-described $45 \mathrm{kDa}$ variant is probably not a product of autocatalysis, as MT4-MMP transfected MDCKs lack these forms. In addition, furin inhibition did not alter the protein amount of the $45 \mathrm{kDa}$ form thus it is formed while the MT4-MMP catalytic domain is blocked by the propeptide. Proteinase inhibitor experiments could enlighten the origin of the $45 \mathrm{kDa}$ MT4-MMP variants. The abundance of the $45 \mathrm{kDa}$ forms in the tissues led us to believe that those forms are not mere degradation products. We are currently studying the formation of these forms as well as possible functions.

The low amount of $69 \mathrm{kDa}$ MT4-MMP in the tissue samples suggests that this protein variant is rapidly processed into either the $58 \mathrm{kDa}$ or the $45 \mathrm{kDa}$ form. The generation of the $45 \mathrm{kDa}$ form might represent a regulatory pathway where the protein is prevented from maturation. This regulation could be disrupted in melanoma leading to increased action of MT4-MMP. The MT4-MMP has no appreciable activity towards matrix components, like collagen or fibrin. However, it is able to cleave other matrix components and proteins that might facilitate melanoma progression. One major feature of tumor progression is increased cell migration. In zebrafish, the loss of function mutation of MT4-MMP resulted in impaired migration of neural crest cells, which are the precursors of melanocytes [32]. Melanocyte distribution was subsequently altered and the authors concluded that MT4-MMP is needed for proper neural crest cell/ melanocyte migration [32]. Migration was also impaired in smooth vascular muscle cells in the aorta in MT4-MMP deficient mice [7]. This was due to the lack of osteopontin cleavage in the MT4-MMP $/$ - mice [7]. Osteopontin is a glycoprotein in the ECM with versatile functions in tumor progression, including the enhancement of tumor cell migration [33-35]. Hence, increased MT4-MMP activity could result in increased migratory potential in tumors due to osteopontin cleavage. We are currently investigating MT4MMPs role in the migratory potential of melanoma cells and the underlying mechanisms. Preliminary data from our lab indicate that down-regulation of MT4-MMP in SK-Mel28 cells results in a reduced migration of the cells.

Another prerequisite for tumor progression is angiogenesis. The activity of ADAMTS4 has been associated with melanoma growth and angiogenesis in mice [36]. ADAMTS4 is activated by MT4-MMP [24]. This connection has been widely studied in arthritis due to ADAMTS4 enzymatic activity towards aggrecan which results in degradation of cartilage and inflammation facilitating the progression of arthritis [16]. In melanoma, ADAMTS4 seems to have double-edged functions. When inactive - still carrying the propeptide - ADAMTS4 exhibits anti-tumorigenic features which is reversed upon propeptide cleavage [36].

Overexpression of the active MT4-MMP could therefore lead to increased activation of pro-tumorigenic factors in the ECM. However, future studies should also focus on physiological roles of MT4-MMP, as its expression was comparable in skin, nevi and malignant tissues.

Together, our results propose human metastatic SK-Mel-28 melanoma cells as novel model for MT4-MMP research and provide an insight into the different forms of MT4-MMP as well as their subcellular location. Future studies should distinguish between the different MT4-MMP forms and refer to the $58 \mathrm{kDa}$ from as the active protein.

\section{Acknowledgments}

We thank Dr. Nor Eddine Sounni for providing the MT4-MMP pcDNA3.1 plasmid.

\section{Disclosure Statement}

The authors declare no conflict of interest

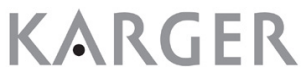




\section{Cellular Physiology Cell Physiol Biochem 2017;42:198-210 \begin{tabular}{ll|l}
\cline { 2 - 3 } and Biochemistry 10.1159/000477311 & $\begin{array}{l}\text { O } 2017 \text { The Author(s). Published by S. Karger AG, Basel } \\
\text { www.karger.com/cpb }\end{array}$ \\
\cline { 2 - 3 }
\end{tabular}}

Hieronimus et al.: MT4-MMP Forms in Melanoma Cell Lines

\section{References}

1 Sounni NE, Paye A, Host L, Noel A: MT-MMPS as Regulators of Vessel Stability Associated with Angiogenesis. Front Pharmacol 2011;2:111.

-2 Sohail A, Sun Q Zhao H, Bernardo MM, Cho JA, Fridman R: MT4-(MMP17) and MT6-MMP (MMP25), A unique set of membrane-anchored matrix metalloproteinases: properties and expression in cancer. Cancer Metastasis Rev 2008;27:289-302.

3 Kolkenbrock H, Essers L, Ulbrich N, Will H: Biochemical characterization of the catalytic domain of membrane-type 4 matrix metalloproteinase. Biol Chem 1999;380:1103-1108.

4 Radichev IA, Remacle AG, Shiryaev SA, Purves AN, Johnson SL, Pellecchia M, Strongin AY: Biochemical characterization of the cellular glycosylphosphatidylinositol-linked membrane type-6 matrix metalloproteinase. J Biol Chem 2010;285:16076-16086.

-5 Puente XS, Pendas AM, Llano E, Velasco G, Lopez-Otin C: Molecular cloning of a novel membrane-type matrix metalloproteinase from a human breast carcinoma. Cancer Res 1996;56:944-949.

6 Rikimaru A, Komori K, Sakamoto T, Ichise H, Yoshida N, Yana I, Seiki M: Establishment of an MT4-MMPdeficient mouse strain representing an efficient tracking system for MT4-MMP/MMP-17 expression in vivo using beta-galactosidase. Genes Cells 2007;12:1091-1100.

7 Martin-Alonso M, Garcia-Redondo AB, Guo D, Camafeita E, Martinez F, Alfranca A, Mendez-Barbero N, Pollan A, Sanchez-Camacho C, Denhardt DT, Seiki M, Vazquez J, Salaices M, Redondo JM, Milewicz D, Arroyo AG: Deficiency of MMP17/MT4-MMP Proteolytic Activity Predisposes to Aortic Aneurysm in Mice. Circ Res 2015;117:e13-26.

8 Grant GM, Giambernardi TA, Grant AM, Klebe RJ: Overview of expression of matrix metalloproteinases (MMP-17, MMP-18, and MMP-20) in cultured human cells. Matrix Biol 1999;18:145-148.

-9 Nuttall RK, Pennington CJ, Taplin J, Wheal A, Yong VW, Forsyth PA, Edwards DR: Elevated membrane-type matrix metalloproteinases in gliomas revealed by profiling proteases and inhibitors in human cancer cells. Mol Cancer Res 2003;1:333-345.

10 Kajita M, Kinoh H, Ito N, Takamura A, Itoh Y, Okada A, Sato H, Seiki M: Human membrane type-4 matrix metalloproteinase (MT4-MMP) is encoded by a novel major transcript: isolation of complementary DNA clones for human and mouse mt4-mmp transcripts. FEBS Lett 1999;457:353-356.

11 Gauthier M-C, Racine C, Ferland C, Flamand N, Chakir J, Tremblay GM, Laviolette M: Expression of membrane type-4 matrix metalloproteinase (metalloproteinase-17) by human eosinophils. The International Journal of Biochemistry \& Cell Biology 2003;35:1667-1673.

12 Plaisier M, Koolwijk P, Hanemaaijer R, Verwey RA, van der Weiden RM, Risse EK, Jungerius C, Helmerhorst FM, van Hinsbergh VW: Membrane-type matrix metalloproteinases and vascularization in human endometrium during the menstrual cycle. Mol Hum Reprod 2006;12:11-18.

13 Chabottaux V, Sounni NE, Pennington CJ, English WR, van den Brule F, Blacher S, Gilles C, Munaut C, Maquoi E, Lopez-Otin C, Murphy G, Edwards DR, Foidart JM, Noel A: Membrane-type 4 matrix metalloproteinase promotes breast cancer growth and metastases. Cancer Res 2006;66:5165-5172.

14 English WR, Puente XS, Freije JM, Knauper V, Amour A, Merryweather A, Lopez-Otin C, Murphy G: Membrane type 4 matrix metalloproteinase (MMP17) has tumor necrosis factor-alpha convertase activity but does not activate pro-MMP2. J Biol Chem 2000;275:14046-14055.

15 Rozanov DV, Hahn-Dantona E, Strickland DK, Strongin AY: The low density lipoprotein receptor-related protein LRP is regulated by membrane type-1 matrix metalloproteinase (MT1-MMP) proteolysis in malignant cells. J Biol Chem 2004;279:4260-4268.

-16 Patwari P, Gao G, Lee JH, Grodzinsky AJ, Sandy JD: Analysis of ADAMTS4 and MT4-MMP indicates that both are involved in aggrecanolysis in interleukin-1-treated bovine cartilage. Osteoarthritis Cartilage 2005;13:269-277.

17 Huang CH, Yang WH, Chang SY, Tai SK, Tzeng C-H, Kao JY, Wu KJ, Yang MH: Regulation of MembraneType 4 Matrix Metalloproteinase by SLUG Contributes to Hypoxia-Mediated Metastasis. Neoplasia 2009;11:1371-1382.

18 Rizki A, Weaver VM, Lee SY, Rozenberg GI, Chin K, Myers CA, Bascom JL, Mott JD, Semeiks JR, Grate LR, Mian IS, Borowsky AD, Jensen RA, Idowu MO, Chen F, Chen DJ, Petersen OW, Gray JW, Bissell MJ: A human breast cell model of preinvasive to invasive transition. Cancer Res 2008;68:1378-1387. 


\section{Cellular Physiology Cell Physiol Biochem 2017;42:198-210 \begin{tabular}{l|l} 
DOI: 10.1159/000477311 & $\begin{array}{l}\text { O 2017 The Author(s). Published by S. Karger AG, Basel } \\
\text { www.karger.com/cpb }\end{array}$
\end{tabular}}

Hieronimus et al.: MT4-MMP Forms in Melanoma Cell Lines

19 Sohail A, Marco M, Zhao H, Shi Q, Merriman S, Mobashery S, Fridman R: Characterization of the dimerization interface of membrane type 4 (MT4)-matrix metalloproteinase. J Biol Chem 2011;286:3317833189.

20 Chabottaux V, Ricaud S, Host L, Blacher S, Paye A, Thiry M, Garofalakis A, Pestourie C, Gombert K, Bruyere F, Lewandowsky D, Tavitian B, Foidart JM, Duconge F, Noel A: Membrane-type 4 matrix metalloproteinase (MT4-MMP) induces lung metastasis by alteration of primary breast tumour vascular architecture. J Cell Mol Med 2009;13:4002-4013.

21 Buk DM, Waibel M, Braig C, Martens AS, Heinrich PC, Graeve L: Polarity and lipid raft association of the components of the ciliary neurotrophic factor receptor complex in Madin-Darby canine kidney cells. J Cell Sci 2004;117:2063-2075.

-22 Host L, Paye A, Detry B, Blacher S, Munaut C, Foidart JM, Seiki M, Sounni NE, Noel A: The proteolytic activity of MT4-MMP is required for its pro-angiogenic and pro-metastatic promoting effects. Int J Cancer 2012;131:1537-1548.

23 Fu HL, Sohail A, Valiathan RR, Wasinski BD, Kumarasiri M, Mahasenan KV, Bernardo MM, Tokmina-Roszyk D, Fields GB, Mobashery S, Fridman R: Shedding of discoidin domain receptor 1 by membrane-type matrix metalloproteinases. J Biol Chem 2013;288:12114-12129.

24 Gao G, Plaas A, Thompson VP, Jin S, Zuo F, Sandy JD: ADAMTS4 (aggrecanase-1) activation on the cell surface involves C-terminal cleavage by glycosylphosphatidyl inositol-anchored membrane type 4-matrix metalloproteinase and binding of the activated proteinase to chondroitin sulfate and heparan sulfate on syndecan-1. J Biol Chem 2004;279:10042-10051.

25 Sharom FJ, Lehto MT: Glycosylphosphatidylinositol-anchored proteins: structure, function, and cleavage by phosphatidylinositol-specific phospholipase C. Biochem Cell Biol 2002;80:535-549.

26 Vogel C, Marcotte EM: Insights into the regulation of protein abundance from proteomic and transcriptomic analyses. Nat Rev Genet 2012;13:227-232.

-27 Kohrmann A, Kammerer U, Kapp M, Dietl J, Anacker J: Expression of matrix metalloproteinases (MMPs) in primary human breast cancer and breast cancer cell lines: New findings and review of the literature. BMC Cancer 2009;9:188.

28 Hoek KS, Schlegel NC, Eichhoff OM, Widmer DS, Praetorius C, Einarsson SO, Valgeirsdottir S, Bergsteinsdottir K, Schepsky A, Dummer R, Steingrimsson E: Novel MITF targets identified using a twostep DNA microarray strategy. Pigment Cell Melanoma Res 2008;21:665-676.

29 Boon L, Ugarte-Berzal E, Vandooren J, Opdenakker G: Glycosylation of matrix metalloproteases and tissue inhibitors: present state, challenges and opportunities. Biochem J 2016;473:1471-1482.

30 Zhao H, Sohail A, Sun Q, Shi Q, Kim S, Mobashery S, Fridman R: Identification and role of the homodimerization interface of the glycosylphosphatidylinositol-anchored membrane type 6 matrix metalloproteinase (MMP25). J Biol Chem 2008;283:35023-35032.

-31 Kang T, Yi J, Guo A, Wang X, Overall CM, Jiang W, Elde R, Borregaard N, Pei D: Subcellular distribution and cytokine- and chemokine-regulated secretion of leukolysin/MT6-MMP/MMP-25 in neutrophils. J Biol Chem 2001;276:21960-21968.

-32 Leigh NR, Schupp MO, Li K, Padmanabhan V, Gastonguay A, Wang L, Chun CZ, Wilkinson GA, Ramchandran R: Mmp17b is essential for proper neural crest cell migration in vivo. PLoS One 2013;8:e76484.

33 Kiss T, Ecsedi S, Vizkeleti L, Koroknai V, Emri G, Kovacs N, Adany R, Balazs M: The role of osteopontin expression in melanoma progression. Tumour Biol 2015;36:7841-7847.

-34 Li Y, Xie Y, Cui D, Ma Y, Sui L, Zhu C, Kong H, Kong Y: Osteopontin Promotes Invasion, Migration and Epithelial-Mesenchymal Transition of Human Endometrial Carcinoma Cell HEC-1A Through AKT and ERK1/2 Signaling. Cell Physiol Biochem 2015;37:1503-1512.

-35 Angelucci A, Festuccia C, Gravina GL, Muzi P, Bonghi L, Vicentini C, Bologna M: Osteopontin enhances the cell proliferation induced by the epidermal growth factor in human prostate cancer cells. Prostate 2004;59:157-166.

-36 Rao N, Ke Z, Liu H, Ho CJ, Kumar S, Xiang W, Zhu Y, Ge R: ADAMTS4 and its proteolytic fragments differentially affect melanoma growth and angiogenesis in mice. Int J Cancer 2013;133:294-306. 